\title{
Influence of Different Growing Media on Plant Growth and Fruit Yield of Strawberry (Fragaria $\times$ Ananassa Duch.) Cv. Chandler Grown under Protected Conditions
}

\author{
Mamta Thakur ${ }^{1}$ and Bunty Shylla ${ }^{2 *}$ \\ ${ }^{1}$ Department of Fruit Science, Dr. Y S Parmar University of Horticulture and Forestry, \\ Nauni-173230, Solan, HP, India \\ ${ }^{2}$ Horticulture Research and Training Station and KVK, Kandaghat, HP, India \\ *Corresponding author
}

\section{A B S T R A C T}

\begin{tabular}{|l|}
\hline Ke y w or d s \\
$\begin{array}{l}\text { Strawberry (Fragaria } \times \\
\text { ananassa Duch.) cv. } \\
\text { Chandler }\end{array}$ \\
\hline Article Info \\
\hline $\begin{array}{l}\text { Accepted: } \\
23 \text { March } 2018 \\
\text { Available Online: } \\
10 \text { April } 2018\end{array}$ \\
\hline
\end{tabular}

Introduction

Strawberry (Fragaria $\times$ ananassa Duch.), a member of the family Rosaceae, is a soft fruited, short-day herbaceous perennial plant that can successfully be grown at optimum day temperatures of $22^{\circ} \mathrm{C}$ to $25^{\circ} \mathrm{C}$ and night temperatures of $7^{\circ} \mathrm{C}$ to $13^{\circ} \mathrm{C}$ (De and Bhattacharjee, 2012). Commercially grown strawberry (Fragaria x ananassa Duch.) is a monoecious octoploid $(2 n=56)$ hybrid of two dioecious octoploid species, namely, Fragaria chiloensis Duch. and Fragaria virginiana Duch. (Bowling 2000) with a basic chromosome number (x) of 7. Botanically, strawberry is an aggregate fruit having seeds on the surface of a red fleshy receptacle (Darnell, 2003).

The last decade has witnessed the emergence of strawberry as the leading fruit in the category of soft berries. The area and production under strawberry in the world has increased logarithmically during the last two decades as much of the crop is being grown under protected structures. In India, strawberry is cultivated on a commercial scale in the states of Maharashtra, Punjab, Haryana, Delhi, parts of Himachal Pradesh, Jammu \& Kashmir, Uttrakhand, Uttar Pradesh, West 
Bengal (Darjeeling hills) and Rajasthan (Rana and Chandel, 2003). Strawberry cultivation In Himachal Pradesh is in its infancy and has gained momentum in the recent past.

The major drawback however lies with the non-availability of good and healthy planting material owing to soil borne pathogens, nematodes and the soil conditions. Soil-borne pathogens are often associated with severe production losses in strawberry culture. To eliminate soil borne diseases and pests, the use of soilless growing media is therefore of utmost importance and is gaining popularity.

A wide variety of soilless media are currently in use in different parts of the world to act as suitable substitutes for soil (De-Rijck and Schrevens, 1998). Out of these growing media, the most commonly used soilless growing media for strawberries are peat moss, rockwool, perlite and cocopeat. The properties of the constituents of different growing media are known to have direct and indirect effects on plant growth and productivity. Among all properties of growing media, pore space, water holding capacity, bulk density, $\mathrm{pH}$, soluble salt content and distribution of the particles size are important physical and chemical properties.

\section{Materials and Methods}

The present investigation was cvonducted at the Horticultural Research \& Training Station and Krishi Vigyan Kendra (HRTS and KVK) Kandaghat, Solan in Himachal Pradesh during the cropping seasons of 2015-16 and 2016-17 using Completely Randomized Block Design (CRBD) for statistical analysis of the results obtained during the courase of studies. The experiment had six treatments, each with four replications consisting 24 beds $(1 \times 1 \mathrm{~m})$ in which strawberry cultivar 'Chandler' runners were planted at a spacing of 20x $20 \mathrm{~cm}$ during October, 2015 and 2016.
The beds were filled with different media according to the treatments $\left(\mathrm{T}_{1}-\mathrm{T}_{6}\right)$ and subsequently lined with black polythene sheet upto twelve inches. The plants were irrigated at 1-2 days interval through microsprinkler irrigation during the initial stages and later by using drip irrigation during fruiting stage while recommended dose of fertilizers were applied through fertigation using soluble fertilizers (19:19:19). All plants were subjected to uniform cultural practices during the course of investigations. Ten plants per treatment were randomly marked for recording the observations.

The effects of growing media were observed by determining plant height $(\mathrm{cm})$, leaf area $\left(\mathrm{cm}^{2}\right)$, number of leaves, number of crowns, root length $(\mathrm{cm})$, number of runners and length of runners $(\mathrm{cm})$ while effects on yield were evaluated by determining yield per plant (g) and yield per hectare (t/ha). The plant height $(\mathrm{cm})$, number of leaves per plant, number of crowns per plant, root length, number of runners per plant, length of runners, number of flowers, per cent berry set and yield per plant (g) were recorded as per standard practices. The leaf area was measured by leaf area meter (Licor-Model 3100) and expressed in square centimeter $\left(\mathrm{cm}^{2}\right)$. Statistical analysis of the data was carried out by the method suggested by Panse and Sukhatme by using MS-Excel and OPSTAT (Sheoran et al., 1998).

\section{Results and Discussion}

\section{Effect of growing media on plant growth}

The data pertaining to the growth characteristics presented in Table 1 indicated that perlite in combination with FYM significantly influenced the vegetative growth parameters particularly plant height, number of leaves and leaf area during both the years of investigation. A critical look at the pooled data 
revealed that the maximum plant height (29.19 $\mathrm{cm})$, number of leaves (18.31) and leaf area $\left(135.08 \mathrm{~cm}^{2}\right)$ were observed under perlite + FYM $\left(\mathrm{T}_{2}\right)$ treatment and the minimum plant height $(25.28 \mathrm{~cm})$, number of leaves (14.70) and leaf area $\left(120.74 \mathrm{~cm}^{2}\right)$ were recorded under soil + FYM $\left(\mathrm{T}_{6}\right)$ treatment. Similar results were obtained on the effect of different growing media in case of leaf area and number of crowns. Additionally, on the basis of statistical analysis of the data presented in Table 2, it was observed that different growing media had no significant effect on the number of crowns.

The maximum enhancement in plant growth under $\mathrm{T}_{2}$ treatment could be attributed to better water holding capacity and nutrient availability which in turn promotes better vegetative growth (Beardsell et al., 1979, Anagnostou and Vassilakakis 1995 and Chhukit 2009). These observations are in conformity with the findings of Verdonck et al., (1981) and Traka-Mavrona et al., (2001) who also observed better growth performances when perlite-based mixtures were used. Perlite alone has also been reported) to have excellent growth performance when used as a substrate in hydroponic culture (Hall et al., 1988).

The runner production and root length were significantly influenced by different growing media treatments which is evident from the data set out in Table 3. A perusal of pooled data reveals that the maximum root length
(19.16) was recorded under perlite + FYM $\left(\mathrm{T}_{2}\right)$ treatment which was however statistically at par with all other treatments except for the control $\left(\mathrm{T}_{6}\right)$ treatment. Maximum number of runners (40.00) was produced under perlite + FYM $\left(\mathrm{T}_{2}\right)$ treatment which was statistically at par with perlite treatment whereas the least number of runners were observed under the control $\left(\mathrm{T}_{6}\right)$ treatment.

These findings go in line with the observations made by Joshi (2003) who also reported that perlite when used in combination as a growing media resulted in better aeration and good nutrient supply. This ultimately results in more runner production and subsequently more plantlets per runner.

Studies conducted by various workers have indicated at perlite and its combination mixture being a substrate with excellent features capable of improving growth and development of plants grown in soilless cultivation owing to its high water retention capacity which increases water efficiency (Djedidi et al., 1999 and Inden and Torres 2004). Various workers (Bartczak et al., 2007, Albaho et al., 2009, Ayesha et al., 2011 and Hesami et al., 2012) have substantiated this feature by elaborating that the use of different organic and inorganic substrates in appropriate proportion optimizes water and oxygen holding capacity thus allowing better nutrient uptake required for sufficient growth and development.

\section{Treatments}

\begin{tabular}{|l|l|}
\hline $\mathrm{T}_{1}:$ & Perlite \\
\hline $\mathrm{T}_{2}:$ & Perlite + FYM $(1: 1)$ \\
\hline $\mathrm{T}_{3}:$ & Cocopeat \\
\hline $\mathrm{T}_{4}:$ & Cocopeat + FYM $(1: 1)$ \\
\hline $\mathrm{T}_{5}:$ & Perlite + Cocopeat + FYM $(1: 1: 1)$ \\
\hline $\mathrm{T}_{6}:$ & Soil+ FYM (Control)
\end{tabular}


Table.1 Effect of different growing media on plant height and number of leaves in strawberry cv. Chandler

\begin{tabular}{|l|c|c|c|c|c|c|}
\hline \multicolumn{1}{c|}{ Treatments } & \multicolumn{3}{|c|}{ Plant Height $(\mathbf{c m})$} & \multicolumn{3}{c|}{ Number of leaves per plant } \\
\hline & $\mathbf{2 0 1 6}$ & $\mathbf{2 0 1 7}$ & Pooled & $\mathbf{2 0 1 6}$ & $\mathbf{2 0 1 7}$ & Pooled \\
\hline $\mathrm{T}_{1}$ Perlite & 28.19 & 28.48 & 28.34 & 18.33 & 16.55 & 17.44 \\
\hline $\mathrm{T}_{2}$ Perlite + FYM (1:1) & 29.38 & 28.88 & 29.19 & 16.63 & 19.98 & 18.31 \\
\hline $\mathrm{T}_{3}$ Cocopeat & 26.13 & 26.18 & 26.15 & 14.59 & 15.74 & 15.56 \\
\hline $\mathrm{T}_{4}$ Cocopeat + FYM $(1: 1)$ & 26.75 & 26.28 & 26.51 & 15.37 & 16.58 & 16.44 \\
\hline $\mathrm{T}_{5}$ Perlite + Cocopeat + FYM (1:1:1) & 27.63 & 27.00 & 27.09 & 16.30 & 17.91 & 16.25 \\
\hline $\mathrm{T}_{6}$ Soil + FYM & 25.38 & 25.18 & 25.28 & 13.75 & 15.65 & 14.70 \\
\hline $\mathrm{CD}_{0.05}$ & 1.36 & 0.76 & 0.79 & 0.93 & 1.93 & 1.18 \\
\hline
\end{tabular}

Table.2 Effect of different growing media on leaf area and number of crowns in strawberry cv. Chandler

\begin{tabular}{l|}
\hline Treatments \\
\hline $\mathrm{T}_{1}$ Perlite \\
\hline $\mathrm{T}_{2}$ Perlite + FYM $(1: 1)$ \\
\hline $\mathrm{T}_{3}$ Cocopeat \\
\hline $\mathrm{T}_{4}$ Cocopeat + FYM $(1: 1)$ \\
\hline $\mathrm{T}_{5}$ Perlite + Cocopeat + FYM $(1: 1: 1)$ \\
\hline $\mathrm{T}_{6}$ Soil + FYM \\
\hline $\mathrm{CD}_{0.05}$ \\
\hline
\end{tabular}

\begin{tabular}{|c|c|c|c|c|c|}
\hline \multicolumn{3}{|c|}{ Leaf area per ten leaves } & \multicolumn{3}{c|}{ Number of crowns } \\
\hline $\mathbf{c m})^{\mathbf{2}}$ & & & \\
\hline $\mathbf{2 0 1 6}$ & $\mathbf{2 0 1 7}$ & Pooled & $\mathbf{2 0 1 6}$ & $\mathbf{2 0 1 7}$ & Pooled \\
\hline 125.67 & 130.07 & 127.87 & 3.10 & 2.65 & 2.88 \\
\hline 135.77 & 134.40 & 135.08 & 3.15 & 2.80 & 2.98 \\
\hline 124.80 & 126.39 & 125.60 & 2.69 & 2.68 & 2.68 \\
\hline 123.81 & 126.41 & 125.11 & 2.49 & 2.63 & 2.56 \\
\hline 125.22 & 126.74 & 125.98 & 2.85 & 2.63 & 2.74 \\
\hline 120.25 & 121.23 & 120.74 & 2.45 & 2.60 & 2.53 \\
\hline 2.30 & 2.50 & 1.38 & NS & NS & NS \\
\hline
\end{tabular}

Table.3 Effect of different growing media on root length, number of runners and length of runners in strawberry cv. Chandler

\begin{tabular}{|l|c|c|c|c|c|c|}
\hline \multicolumn{1}{|c|}{ Treatments } & \multicolumn{3}{|c|}{ Root length (cm) } & \multicolumn{3}{c|}{ Number of runners } \\
\hline & $\mathbf{2 0 1 5}$ & $\mathbf{2 0 1 6}$ & Pooled & $\mathbf{2 0 1 5}$ & $\mathbf{2 0 1 6}$ & Pooled \\
\hline $\mathrm{T}_{\mathbf{1}}$ Perlite & 18.91 & 20.63 & 19.13 & 37.00 & 41.50 & 39.25 \\
\hline $\mathrm{T}_{2}$ Perlite + FYM (1:1) & 18.38 & 19.41 & 19.16 & 40.25 & 39.75 & 40.00 \\
\hline $\mathrm{T}_{3}$ Cocopeat & 16.44 & 17.49 & 16.70 & 31.75 & 36.00 & 34.75 \\
\hline $\mathrm{T}_{4}$ Cocopeat + FYM (1:1) & 16.31 & 17.13 & 16.72 & 32.50 & 36.50 & 34.50 \\
\hline $\mathrm{T}_{5}$ Perlite + Cocopeat + & 17.63 & 18.06 & 17.85 & 35.50 & 37.75 & 36.25 \\
\hline FYM (1:1:1) & 14.75 & 15.00 & 14.88 & 31.00 & 31.50 & 31.25 \\
\hline $\mathrm{T}_{6}$ Soil + FYM & 1.76 & 2.00 & 2.80 & 1.64 & 1.73 & 1.14 \\
\hline CD $_{0.05}$ & & & & & & \\
\hline
\end{tabular}


Table.4 Effect of different growing media on yield per plant and yield per hectare in strawberry cv. Chandler

\begin{tabular}{|l|c|c|c|c|c|c|}
\hline Treatments & \multicolumn{3}{|c|}{ Yield per plant $(\mathbf{g})$} & \multicolumn{3}{c|}{ Yield per ha (t/ha) } \\
\hline & $\mathbf{2 0 1 6}$ & $\mathbf{2 0 1 7}$ & Pooled & $\mathbf{2 0 1 6}$ & $\mathbf{2 0 1 7}$ & Pooled \\
\hline $\mathrm{T}_{1}$ Perlite & 194.77 & 208.00 & 201.39 & 48.69 & 52.00 & 50.35 \\
\hline $\mathrm{T}_{2}$ Perlite + FYM $(\mathbf{1 : 1 )}$ & 201.39 & 205.23 & 203.32 & 50.35 & 51.31 & 50.83 \\
\hline $\mathrm{T}_{3}$ Cocopeat & 186.33 & 191.95 & 189.14 & 46.58 & 47.99 & 47.29 \\
\hline $\mathrm{T}_{4}$ Cocopeat + FYM $(\mathbf{1 : 1 )}$ & 186.97 & 194.06 & 190.52 & 46.74 & 48.52 & 47.63 \\
\hline $\mathrm{T}_{5}$ Perlite + Cocopeat + FYM (1:1:1) & 192.97 & 200.30 & 196.64 & 48.24 & 50.08 & 49.16 \\
\hline $\mathrm{T}_{6}$ Soil + FYM & 183.52 & 186.69 & 185.11 & 45.88 & 46.67 & 46.28 \\
\hline $\mathrm{CD}_{0.05}$ & 1.44 & 0.91 & 0.79 & 0.36 & 0.23 & 0.19 \\
\hline
\end{tabular}

\section{Effect of growing media on fruit yield}

From the data presented in Table 4, it is apparent that the differences among various treatments were found to be significant in respect of berry yield per plant and yield per hectare during both the years of investigation. The pooled data reveals that the maximum berry yield per plant (203.32 g) and yield per hectare (50.83 t/ha) was observed under perlite + FYM $\left(\mathrm{T}_{2}\right)$ treatment. However, minimum berry yield per plant $(185.11 \mathrm{~g})$ and yield per hectare $(46.28 \mathrm{t} / \mathrm{ha})$ was recorded under soil + FYM $\left(\mathrm{T}_{6}\right)$ treatment. The positive influence of perlite and its mixtures on better root development may result in improved aeration thus forming greater root system which may have promoted shoot nutrient uptake leading to increased berry yield. Similar reports indicating of increased yield in perlite and its mixtures have been reported in Sweet Charlie strawberry (Cantliffe et al., 2008) and Camarosa strawberry (Hochmuth 2008).

The results obtained in these studies are in harmony with the findings of Linardakis and Manios (1991), Cantliffe et al., (2008), Yavari et al., (2008), Mashadi et al., (2009) and Rostami et al., (2014), who also observed that the yield of strawberry significantly differed when substrates composed of different ratios of cocopeat, perlite and FYM were used. Different combinations of media have also been reported to improve aeration resulting in the formation of better root system (Yuan et al., 1996 and Verdonck and Demeyer, 2004) and resulting in higher yield (Du et al., 2007 and Albaho et al., 2009).

A critical analysis of the results obtained during the present course of investigations leads to the conclusion that among the different growing media used, perlite in combination with FYM (1:1) is the most appropriate media for obtaining better growth, higher runner production and better yield of strawberry.

\section{References}

Albaho M, Bhat N, Abo-Rezq H and Thomas B. 2009. Effect of three different substrates on growth and yield of two cultivars of strawberry. European Journal of Scientific Research 28: 227233.

Anagnostou K and Vasilakakis MD. 1995. Effect of substrate and cultivar on earliness, plant productivity and fruit quality of strawberry. Acta Horticulturae 379: 267-274.

Ayesha R, Fatima N, Ruqayya M, Faheem H, Qureshi KM, Hafiz IA, Khan KS, Ali U and Kamal A. 2011. Influence of different growth media on the fruit 
quality and reproductive growth parameters of strawberry (Fragaria $\times$ ananassa Duch.). Journal of Medicinal Plants Research 5: 6224-6232.

Bartczak M, Pietrowska M and Knaflewski M. 2007. Effect of substrate on vegetative quality of strawberry plants (Fragaria $\times$ ananassa Duch.) produced by a soilless method. Folia Horticulturae 19: 39-46.

Beardsell DV, Nicholas DG and Jones DL. 1979. Physical properties of nursery potting mixture. Scientia Horticulturae 11: $1-8$.

Bowling BL. 2000. The Berry Grower's Companion. Timber Press Inc., Portland, Oregon, USA. 308p.

Cantliffe DJ, Castellanos JZ and Paranjpe AV. 2008. Yield and quality of greenhouse grown strawberries as affected by nitrogen level in coco coir and pine bark media. In: Proceedings of the Florida State Horticultural Society 120: 157-161.

Chhukit K. 2009. Studies on vegetative propagation of Kiwifruit (Actinidia deliciosa). M.Sc. Thesis. Department of Fruit Science, Dr YS Parmar University of Horticulture and Forestry, Solan, HP.

Darnell R. 2003. Strawberry growth and development. In: The Strawberry: A Book for Growers and Others, held at Florida, Gainesville, 2003 (Childers NF ed). Institute of Food and Agricultural Sciences, University of Florida, Gainesville, USA.

De LC and Bhattacharjee SK. 2012. Handbook of Edible Fruits. Aavishkar Publishers, Jaipur 302003 (Rajasthan), India. 312p.

De-Rijck G and Schrevens E. 1998. Distribution of nutrients and water in rockwool slabs. Scientia Horticulturae 72: 277-285.

Djedidi M, Gerasopoulos D and Maloupa E. 1999. The effect of different substrates on the quality of F. Carmello tomatoes (Lycopersicon esculentum Mill.) grown under protection in a hydroponic system. Cahier Options Mediterranneenes 31: 379-383.

Du GD, Guo XW, Wu J and Cai M. 2007. Effect of different media aeration on growth and photosynthetic characteristic of strawberry. College of Horticulture Shenyang Agricultural University, Liaoning, Shenyang.

Hall DA, Hitchon GM and Szmidt RAK. 1988. Perlite culture: A new development in hydroponics. ISOSC proceedings.

Hesami A, Khorami SS, Amini F and Kashkooli AB. 2012. Date-peat as an alternative in hydroponic strawberry production. African Journal of Agricultural Research 7: 3452- 3458.

Hochmuth G. 2008. Containerized strawberry transplants reduce establishment period water use

Inden $\mathrm{H}$ and Torres A. 2004. Comparison of four substrates on the growth and quality of tomatoes. Acta Horticulturae 644: 205-210.

Joshi PS. 2003. Effect of growing media, bioregulators and nutrients on growth, yield and quality of strawberry $c v$. Chandler. PhD Thesis. Department of Fruit Science, Dr YS Parmar University of Horticulture and Forestry, Solan, HP.

Linardakis DK and Manios BI. 1991. Hydroponic culture of strawberries in plastic greenhouse in a vertical system. Acta Horticulturae 287: 317-326.

Mashadi, Jafarloo A, Naseri L, Samadi A and Hanare M. 2009. The types of substrates used in hydroponics culture. In: Proceedings of the First National Conference on Hydroponics and Greenhouse Productions, Isfahan University of Technology, Isfahan, Iran. pp. 351-353. 
Panse VG and Sukhatme PV. 2000. Statistical Methods for Agricultural Workers. Indian Council of Agricultural Research, New Delhi, India. pp. 157165.

Rana RK and Chandel JS. 2003. Effect of biofertilizers and nitrogen on growth, yield and fruit quality of strawberry. Progressive Horticulture 35: 25-30.

Rostami Z, Ghahsare AM and Kavoosi B. 2014. Date palm waste application as culture media for strawberry and its impact on some growth indices and yield components. Agricultural Communications 2: 15-21.

Sheoran OP, Toonk DS, Kaushik LS, Hasija RC and Pannu RS. 1988. Statistical software package for agricultural research workers. In: Recent Advances in Information Theory, Statistics and Computer Application (Hooda DS and Hasija RC eds). Department of mathematical statistics, CCS HAU, Hisar. pp. 139-143.

Traka-Mavrona E, Gerasopoulos D, Pritsa T and Maloupal E. 2001. Growth, fruit yield and quality of tomato in relation to substrate and nutrient source in a soilless culture system. Acta Horticulturae 548: 173-179.

Verdonck O and Demeyer P. 2004. The influence of the particle sizes on the physical properties of growing media. Acta Horticulturae 644: 99-101.

Verdonck O, Vleeschauwer D and De-Boodt M. 1981. The influence of the substrates on plant growth. Acta Horticulturae 126: 251-258.

Yavari S, Eshghi S, Tafazoli E and Yavari S. 2008. Effects of various organic substrates and nutrient solution on productivity and fruit quality of strawberry 'Selva' (Fragaria $\times$ ananassa Duch.). Journal of Fruit and Ornamental Plant Research 16: 167178.

Yuan LP, Jaj EH and Jonathan PL. 1996. Marigold growth and phosphorus leaching in a soilless medium amended with phosphorus charged alumina. Journal of Horticultural Science 31: $94-$ 98.

\section{How to cite this article:}

Mamta Thakur and Bunty Shylla. 2018. Influence of Different Growing Media on Plant Growth and Fruit Yield of Strawberry (Fragaria $\times$ Ananassa Duch.) Cv. Chandler Grown under Protected Conditions. Int.J.Curr.Microbiol.App.Sci. 7(04): 2724-2730.

doi: https://doi.org/10.20546/ijcmas.2018.704.310 